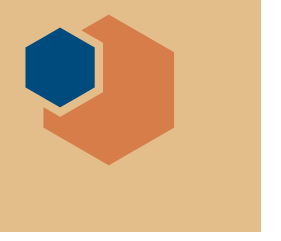

\title{
US grapples with security of the scientific enterprise
}

$\mathrm{F}$ ederally funded scientific advancements have, in many respects, maintained and strengthened US national security. The role of science in general, and materials science in particular, in bolstering national security is broad-spanning from technology developed specifically to aid US military and protect the country; to research-based improvements across health, energy, and environmental stewardship; to the commercialization of a wide variety of science-enabled products and services that drive the US economy. Policymakers in the United States and other countries recognize the dependence of security on science, and members of Congress often cite "national security" as one reason for sponsoring or supporting science-related legislation. The relationship between science and national security is also evident within the executive branch, where many of the departments and agencies that lead scientific research are tasked with enhancing or protecting US security.

But recent concerns, raised by the US intelligence community and a growing number of lawmakers across political parties, question the security of the US scientific enterprise. The security threat centers on alleged exploitation of the US research environment by other countries.

Characterized by openness and collaboration, the US research environment promotes the free flow of ideas, information, and expertise. This environment, where open access to data and results has been encouraged - and in some cases mandated-across federally supported research, has enabled more rapid technological advancement as well as drawn international talent to the United States. But now, the environment that has made the United States a global leader in science and technology is increasingly being viewed as a potential target for exploitation.

A number of hearings have been held in the US Congress over the last two years to both raise the alarm and examine the alleged means of exploitation. During a December 2018 hearing before the US Senate Judiciary Committee, Assistant Attorney General of the National Security Division of the US Department of Justice John C. Demers presented a statement that outlined US intelligence officials' allegations of a multifaceted approach by a country that employs both legal and illegal means "to advance its economic development at our expense." The testimony calls out several areas where the US research environment may be vulnerable, including through access to nontraditional collectors, research partnerships, academic collaborations, and talent recruitment programs.

While there is escalated awareness of the alleged national security threats and vulnerabilities within the research environment, the agencies that fund science research have also taken action to update, clarify, and/or reiterate their policies related to "foreign influence." The National Institutes of Health, National Science Foundation, US Department of Energy, and US Department of Defense (DoD) are among those that both fund materials research and have responded to this issue.

Congress has also begun to take action to protect US research through legislation, starting with the National Defense Authorization Act (NDAA) for fiscal year 2019 (FY 2019 — passed in August 2018). Included within the annual authorization bill was a call for a "whole-of-government strategy" with respect to preventing the "use of intelligence networks to exploit open research and development" that would protect and strengthen national security. The bill also established an initiative within the DoD that would partner with academic institutions to protect researchers working in national security-relevant fields from foreign exploitation; directs the DoD to set up procedures "in the interest of national security" to limit non-US access to technology; and modifies export controls on technologies relevant to national security. 
But these initial mandates have not alleviated congressional concerns about security within science. In fact, according to the Association of Public and Land Grant Universities, over 20 bills related to national security in science have been introduced since the beginning of 2019. While many of these bills haven't gotten any traction, several were offered as amendments during debate of the FY 2020 NDAA.

The version of the FY 2020 NDAA that passed the Senate includes a mandate for oversight of "foreign influence" in academia. The Director of National Intelligence is required to provide an annual report to Congress that details "risks to sensitive research subjects posed by foreign entities...." The report would include a list of sensitive research subjects relevant to national security, a list of foreign entities that pose a national security threat, a list of known and/or suspected attempts by foreign entities to influence academic institutions, and recommendations for mitigation of threats through collaboration between the intelligence and academic communities. Also included within the Senate bill is a provision that would modify the DoD initiative to protect academic researchers from foreign influence (established by the FY 2019 NDAA) to include the development of a list of academic institutions in specific countries that engage in military-related research, are known to recruit for defense programs and/or conceal connections to defense programs, or "pose a serious risk of intangible transfers of defense or engineering technology research."

The US House of Representatives' version of the FY 2020 NDAA was amended to include the Securing American Science and Technology Act (SASTA). This bill mandates the establishment of an interagency working group that will coordinate activities to protect federally funded

\section{Hearings and legislation regarding science and US national security}

\section{Testimonies}

Assistant Attorney General of the National Security Division of the US Department of Justice John C. Demers presented statement: judiciary.senate.gov/imo/media/doc/12-12-18\%20Demers\%20Testimony.pdf

2019 Senate Intelligence Committee Hearing: intelligence.senate.gov/hearings/open-hearing-worldwide-threats

\section{Legislation}

NDAA FY 2019: congress.gov/bill/115th-congress/house-bill/5515

House FY 2020 NDAA: congress.gov/bill/116th-congress/house-bill/2500

Senate FY 2020 NDAA: congress.gov/bill/116th-congress/senate-bill/1790

research from foreign influence and develop "best practices" across federal science agencies. The SASTA also sets up a "National Science, Technology and Security Roundtable" within the National Academies. The roundtable is tasked with bringing together the research (federal, academic, and industry), intelligence, and security communities to identify and assess risks at the nexus of science and security, and to develop best practices to mitigate these risks while also "ensuring the open exchange of ideas and international talent required for scientific progress and American leadership in science and technology."

The NDAA for FY 2020 is now in conference between the House and Senate to reconcile differences. It is impossible to predict what, if any, science and securityrelated provisions will make it into the final version of the bill and become law. The timing of the bill is also uncertain, but there is likely movement or a continuing resolution on the horizon since the new fiscal year started on October 1.

Meanwhile, the scientific community has also had a significant response to the alleged foreign exploitation of the US research environment. They are engaging and advocating in a number of ways. Scientists are writing editorials - warning that hasty policy changes could bring about unintended consequences, jeopardize international collaborations, or create an atmosphere of suspicion that would damage the research enterprise. They are working within their institutions to update policies in a way that will serve and protect science. Best practices are being discussed and shared among universities.

Many scientific professional societies and other science groups are engaging with policymakers to ensure that relevant legislation is informed by those it would impact. This advocacy effort has already had an influence as evidenced by the House's inclusion of the SASTA (which would give scientists a seat at the table at future discussions of science and national security) in its version of the FY 2020 NDAA.

While the complexity of this issue means that the scientific community does not speak with one voice, the advocacy efforts may lead to policies that address the complexities of the issue while preserving the open and collaborative environment of the scientific enterprise.

Jennifer A. Nekuda Malik

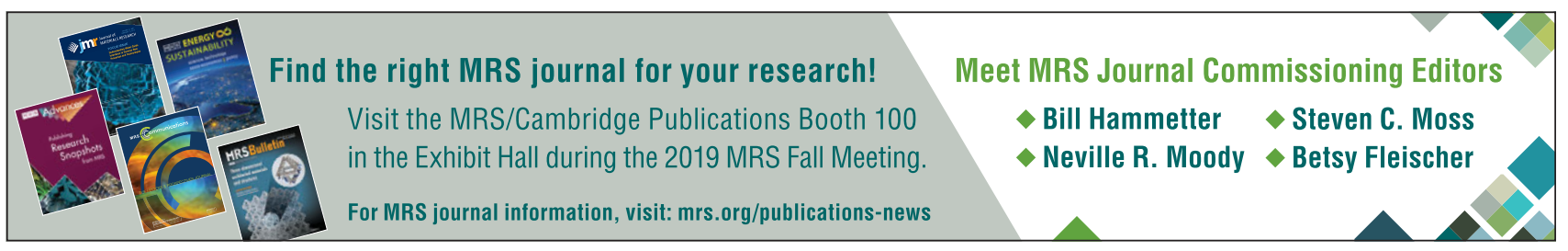

